\title{
Pulmonary hypertension associated with benfluorex exposure
}

\author{
Laurent Savale, Marie-Camille Chaumais, Vincent Cottin, Emmanuel Bergot, \\ Irène Frachon, Grégoire Prevot, Christophe Pison, Claire Dromer, Patrice Poubeau, \\ Nicolas Lamblin, Gilbert Habib, Martine Reynaud-Gaubert, Arnaud Bourdin, \\ Olivier Sanchez, Pascale Tubert-Bitter, Xavier Jaïs, David Montani, Olivier Sitbon, \\ Gérald Simonneau and Marc Humbert
}

ABSTRACT: Benfluorex was marketed in France until 2009, despite its similar pharmacological properties with fenfluramine and its derivatives known to be a cause of pulmonary arterial hypertension (PAH).

The aim of this study is to report clinical and haemodynamic characteristics for patients suffering from pulmonary hypertension $(\mathrm{PH})$ associated with benfluorex exposure that had been identified by the French PAH Network.

85 cases of PH associated with benfluorex exposure were identified by the French PAH Network from June 1999 to March 2011. Of these, 70 patients had confirmed pre-capillary PH. The median duration of exposure was $\mathbf{3 0}$ months, with a median of 108 months between start of exposure and diagnosis of the pulmonary vascular disease. $33 \%$ of all patients also had prior exposure to fenfluramine or dexfenfluramine, and an additional risk factor for $\mathrm{PH}$ was identified in 20 (30\%) out of 70 patients with pre-capillary $\mathrm{PH}$. A quarter of patients in this current series showed coexisting PH and mild-to-moderate cardiac valve involvement.

The results of our study, together with the accumulated data regarding the known toxic effects of fenfluramine and dexfenfluramine, strongly suggest that benfluorex exposure is a potent trigger for PAH.

KEYWORDS: Anorectic agents, benfluorex, fenfluramine derivates, pulmonary hypertension, valvular heart disease

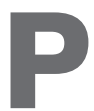
ulmonary arterial hypertension (PAH) is a rare condition characterised by a progressive increase in pulmonary vascular resistance that leads to eventual right heart failure $[1,2]$. An aetiological link between exposure to anorectic agents and PAH has been demonstrated for nearly half a century. In the most recent pulmonary hypertension $(\mathrm{PH})$ guidelines, these cases are included in the group of $\mathrm{PAH}$ induced by exposure to drugs or toxins [3].

2 yrs after the amphetamine derivative aminorex became commercially available in Switzerland, Germany and Austria, a dramatic increase in the number of cases of so-called "primary" $\mathrm{PH}$ was observed $[4,5]$. Compelling geographic and temporal evidence supported a causal role for aminorex in this epidemic. Following these events, a working group of the World Health Organization convened the first World Symposia on Pulmonary Hypertension in Geneva (Switzerland) in 1973. The subsequent publication of the Executive summary document of the symposia provided, for the first time, a consensus on the clinical and pathological classification of the disorder [6].

Norfenfluramine is a metabolically active product of fenfluramine and its derivatives. Exposure to norfenfluramine is known to be associated with both cardiac valvular dysfunction and PAH. Mounting evidence indicates that serotonin contributes to the pathophysiology of $\mathrm{PH}$ by promoting proliferation of pulmonary arterial smooth muscle cells and adventitial fibroblasts [7]. Recent data suggest that fenfluramine and its derivatives can induce pulmonary vascular remodelling through a direct action on the serotonin pathway [8].

Fenfluramine has been commercially licensed in Europe since 1963 as an anorectic agent. The fenfluramine derivative, dexfenfluramine, was first made available in France in 1985 [9]. During the 1980s and 1990s, fenfluramine and its derivatives were widely prescribed throughout Europe. However, a link between fenfluramine exposure and the development of PAH was first suspected in
AFFILIATIONS

For a full list of affiliations, see the Acknowledgements section.

CORRESPONDENCE

M. Humbert

Service de Pneumologie et

Réanimation Respiratoire

Hôpital Bicêtre

78 Rue du Général Leclerc

94270 Le Kremlin Bicêtre

France

E-mail: marc.humbert@bct.aphp.fr

Received:

Oct 292011

Accepted after revision:

March 312012

First published online:

April 202012 
1981 [10]. In 1992, RocHE et al. [11] reported a case series of patients that developed PAH after exposure to dexfenfluramine. The following year, BRENOT et al. [12] reported that $\sim 20 \%$ of patients referred for evaluation of PAH at the Hôpital Antoine Béclère in Clamart (France) had a history of exposure to fenfluramine and/ or one or more of its derivatives [12]. The observation that patients exposed to anorexigens, in particular fenfluramines, were at an increased risk of PAH was subsequently confirmed in the International Primary Pulmonary Hypertension Study [13]. Further evidence of the association was provided by data from the Surveillance Of Pulmonary Hypertension In America (SOPHIA) [14]. Finally, fenfluramine and dexfenfluramine were withdrawn from the French market in 1997.

Benfluorex is a benzoate ester that shares similar structural and pharmacological characteristics with dexfenfluramine and fenfluramine. The active and common metabolite of each of these molecules is norfenfluramine, which itself has a chemical structure similar to that of the amphetamines. Given its pharmacological properties, benfluorex would be expected to have similar toxic effects to the fenfluramine derivatives. However, benfluorex was not subjected to the same restrictions as the fenfluramine derivatives in 1997 in France, at least in part because it was approved as an agent for the treatment of diabetes and the metabolic syndrome and not an anorexigen. As a result, and in spite of case reports, benfluorex remained available in France until November 2009, until compelling data were brought from a case-control study by FRACHON et al. [15] that highlighted the potential cardiotoxic effects, even though benfluorex had been withdrawn from commercial use in other European countries several years previously $[15,16]$. Between 1976 and 1980, benfluorex has been marketed in other European countries including Spain, Greece, Portugal and Italy. Withdrawal of benfluorex in Spain and Italy occurred in 2003 and 2004, respectively, due to the occurrence of cardiac valvulopathy.

We have previously reported a small series of patients with $\mathrm{PAH}$ that had prior exposure to benfluorex [17]. The aim of the current study was to establish the clinical and haemodynamic characteristics and outcomes of patients identified by the French Network of Pulmonary Hypertension with prior exposure to benfluorex and confirmed $\mathrm{PH}$.

\section{PATIENTS AND METHODS}

\section{Patients}

All patients with $\mathrm{PH}$ and a prior history of exposure to benfluorex that were assessed at the French $\mathrm{PH}$ referral centre or one of its associated competent centres were evaluated. Accordingly, all 25 hospitals comprising the French PAH Network, which was established in 2004 as part of the orphan disease programme, were involved in the study. Data was centrally collected and analysed at the French referral centre for severe PH (Hôpital Bicêtre, Univesité Paris-Sud, Le Kremlin Bicêtre, France). According to French legislation, ethics committee agreement and provision of informed consent are not required for retrospective collection of data corresponding to current practice. However, the database was compiled anonymously within the restrictive requirements of the Commission Nationale Informatique et Libertés, the organisation dedicated to privacy, information technology, and civil rights in France.
$\mathrm{PH}$ was defined as a mean pulmonary arterial pressure (PAP) $\geqslant 25 \mathrm{mmHg}$. All patients had undergone initial screening by transthoracic echocardiography and were subsequently sent to a competent centre for suspected $\mathrm{PH}$ without evident sign of left cardiac disease. A right heart catheterisation was systematically performed during the initial assessment in order to confirm the diagnosis of $\mathrm{PH}$, clarify its mechanism and determine its severity.

The type of $\mathrm{PH}$ was defined according to the European Respiratory/European Society of Cardiology (ESC) guidelines [18]. Pre-capillary $\mathrm{PH}$ was defined as mean PAP $\geqslant 25 \mathrm{mmHg}$ and pulmonary capillary wedge pressure $(P \mathrm{pcw}) \leqslant 15 \mathrm{mmHg}$. Mixed pre- and post-capillary PH was defined as mean PAP $\geqslant 25 \mathrm{mmHg}, P$ pcw $>15 \mathrm{mmHg}$ and transpulmonary gradient $\left(\mathrm{TPG}=\right.$ mean PAP $\left.-P_{\mathrm{pcw}}\right)>12 \mathrm{mmHg}$. Post-capillary PH was defined as mean PAP $\geqslant 25 \mathrm{mmHg}, P$ cw $>15 \mathrm{mmHg}$ and TPG $\leqslant 12 \mathrm{mmHg}$.

In line with current guidelines, all patients in whom the diagnosis of $\mathrm{PH}$ was confirmed by right heart catheterisation underwent extensive investigations in order to identify additional possible risk factors for $\mathrm{PH}$ (congenital heart disease, portopulmonary hypertension, HIV infection, connective tissue disease, chronic thromboembolic $\mathrm{PH}$, chronic obstructive or restrictive lung disease, systolic or diastolic left heart disease, haemoglobinopathies etc.).

Details of anorexigen exposure (benfluorex and/or others) were gathered by detailed clinical history either at time of initial work-up or a posteriori depending on each case. The date of onset, the date of last use and the cumulative months of use were established after a patient's interview and confirmed after collecting written prescriptions when available.

\section{Clinical, functional and haemodynamic assessment at baseline evaluation}

Clinical characteristics that included: age, sex, weight (kg), height $(\mathrm{m})$, body mass index $\left(\mathrm{BMI} ; \mathrm{kg} \cdot \mathrm{m}^{-2}\right)$, and cardiovascular risk factors (history of diabetes mellitus, hypertension and dyslipidaemia), were collected from baseline evaluation. Functional status of patients was assessed by modified New York Heart Association functional class and 6-min walk distance (6MWD) (m). Standard right heart catheterisation and acute vasodilator challenge were performed in all patients for diagnostic confirmation. Patients were classified as acute responders according to the current criteria [19].

Baseline clinical characteristics of patients with benfluorexinduced PAH were compared with those of patients from the French referral centre with fenfluramine-induced PAH previously reported by SouzA et al. [20].

\section{Genetic studies}

13 patients with benfluorex-induced $\mathrm{PAH}$ were assessed for BMPR2 germline mutation as previously described [21].

\section{Assessment for associated valvular heart disease}

Transthoracic echocardiography was used to identify and describe associated mitral and/or aortic valve insufficiency and/or morphological valvular abnormalities. 
Valve morphology and function was assessed according to current recommendations [22]. A valvular regurgitation was classified as mild, moderate, moderate-to-severe or severe, based on qualitative, semi-quantitative, and quantitative methods, as recommended. Concerning mechanism, valve movement was considered to be restrictive when valvular mobility was reduced [22]. Mitral orifice area was measured by planimetry using two-dimensional echocardiography according to the recommendations of the ESC [23].

\section{Statistical analysis}

All continuous data are presented as mean \pm SD or median (interquartile range,) as appropriate. Comparison between continuous data was performed using an unpaired t-test. A Chi-squared test was used for group data comparison.

\section{RESULTS}

\section{Number of cases of $\mathrm{PH}$ associated with benfluorex exposure identified by the French PAH Network}

The first case of pre-capillary $\mathrm{PH}$ in a patient with prior exposure to benfluorex was referred to the French PH referral centre in June 1999. In total, between June 1999 and March 2011, 85 cases of PH associated with benfluorex exposure were diagnosed throughout the French PAH Network (fig. 1). Of these, the diagnosis was established at the national referral centre in 30 patients and at satellite centres in 55 patients. Only nine cases were evaluated for the first time between 1999 and 2005. In the remaining 76 cases, the diagnosis of $\mathrm{PH}$ was established between 2006 and 2011 (fig. 2).

Among the 85 cases referenced in this study, five cases have been published by BONDON-GUITTON et al. [24] and four other cases by BOUTET et al. [17].

In 70 patients, $\mathrm{PH}$ was established as "pure" pre-capillary $\mathrm{PH}$ (i.e. without an associated post-capillary component). 13 patients had mixed pre- and post-capillary $\mathrm{PH}$ (as evidenced by a TPG $>12 \mathrm{mmHg}$ ). Two patients were established as having post-capillary $\mathrm{PH}$ without a pre-capillary component.

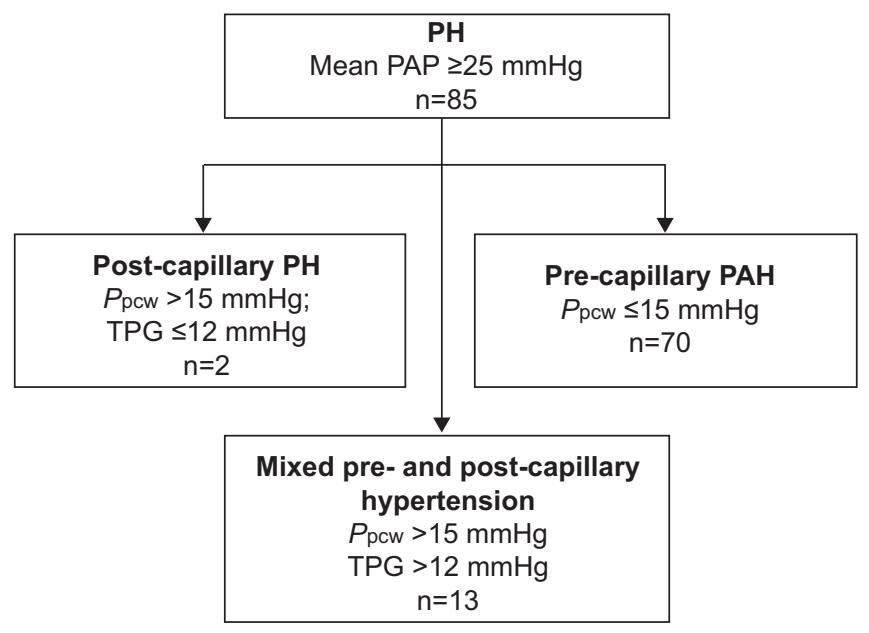

FIGURE 1. Type of benfluorex-associated pulmonary hypertension $(\mathrm{PH})$ identified between January 1999 and March 2011. PAP: pulmonary arterial pressure; Ppcw: pulmonary capillary wedge pressure; TPG: transpulmonary gradient; $\mathrm{PAH}$ : pulmonary arterial hypertension.

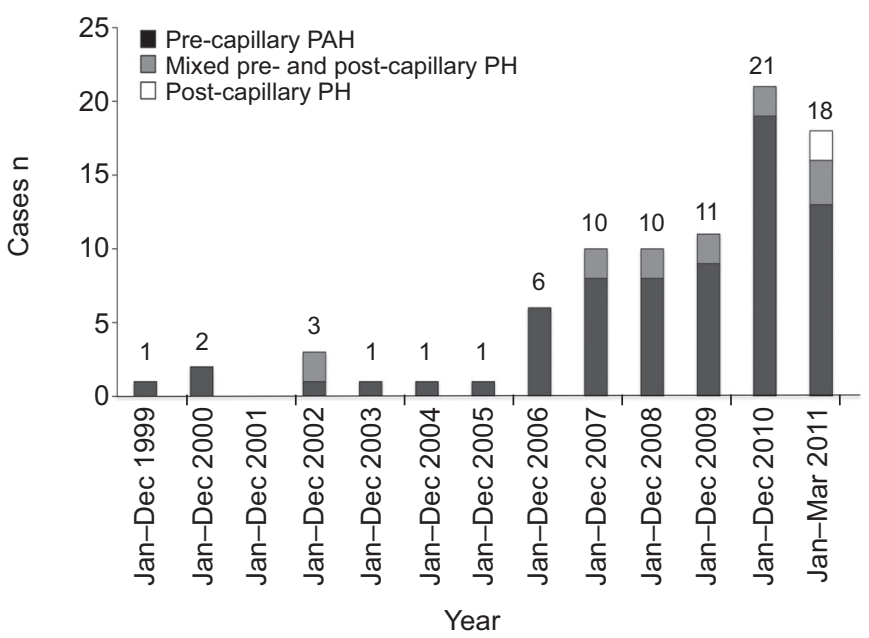

FIGURE 2. Number of newly diagnosed benfluorex-associated pulmonary hypertension (PH) patients each year between January 1999 and March 2011. PAH: pulmonary arterial hypertension.

Accordingly, we deemed that these two patients did not have pulmonary vascular disease per se.

\section{Clinical characteristics}

The median patient age was 62 yrs. Males comprise $22 \%$ of the total cases. The median value for BMI was $30 \mathrm{~kg} \cdot \mathrm{m}^{-2}$. At time of diagnosis of $\mathrm{PH}, 58 \%$ of patients were known to have diabetes mellitus, $44 \%$ had dyslipidaemia and $56 \%$ had systemic hypertension. At least one of these three cardiovascular risk factors was present in $80 \%$ of patients.

\section{Benfluorex exposure}

The median duration of exposure to benfluorex in our patient population was 30 months. It was not possible to accurately establish the duration of benfluorex exposure in 12 patients. The median interval between date of first exposure to benfluorex and date of diagnosis of $\mathrm{PH}$ was 9 yrs. 17 patients were regarded as current users at the time of diagnosis. Finally, for the other patients, median latency between last exposure and the diagnosis of $\mathrm{PH}$ was 5 yrs. 28 (33\%) patients reported exposure to fenfluramine or dexfenfluramine in addition to benfluorex. In all cases, exposure to the fenfluramine derivatives was prior to benfluorex exposure.

\section{Characteristics of patients with "pure" pre-capillary PH}

The majority of patients evaluated in our network had pure pre-capillary $\mathrm{PH}(\mathrm{n}=70,82 \%)$. At time of diagnosis, $58(83 \%)$ out of 70 patients had dyspnoea that was moderate to severe (NHYA functional class III to IV). Median 6MWD was $319 \mathrm{~m}$. The haemodynamic profile of this cohort is summarised in table 1. A positive vasodilator response to inhaled nitric oxide was observed in four (5.7\%) patients.

Among the 70 patients with pre-capillary $\mathrm{PH}$, an additional risk factor for $\mathrm{PH}$ was identified in 21 patients: five cases of connective tissue disease; three cases of chronic obstructive pulmonary disease and one of idiopathic pulmonary fibrosis; four cases of distal chronic thromboembolic PH (CTEPH) and three cases of proximal CTEPH; two cases of cirrhosis; one case 


\begin{tabular}{|c|c|c|c|}
\hline \multirow[t]{2}{*}{$\begin{array}{l}\text { data of } p \\
\text { pulmonar } \\
\text { comparis } \\
\text { fenfluram } \\
\text { PAH }\end{array}$} & \multirow[t]{2}{*}{$\begin{array}{l}\text { atients with } \\
\text { y arterial h } \\
\text { on with a o } \\
\text { ine and de }\end{array}$} & \multirow[t]{2}{*}{$\begin{array}{l}\text { enfluorex-ass } \\
\text { ertension (PAl } \\
\text { ort of patient } \\
\text { nfluramine-as }\end{array}$} & \multirow[t]{2}{*}{$\begin{array}{l}\text { lynamic } \\
\text { ted } \\
\text { iated }\end{array}$} \\
\hline & & & \\
\hline Subjects n & 70 & 109 & \\
\hline Age yrs & $61(51-71)$ & $52(44-59)$ & $<0.0001$ \\
\hline Sex M:F ratio & $1: 3$ & $1: 19$ & $<0.0001$ \\
\hline BMI $\mathrm{kg} \cdot \mathrm{m}^{-2}$ & $30(26-34)$ & 27 (24-33) & $<0.05$ \\
\hline $\begin{array}{l}\text { Delay between first } \\
\text { anorexigen exposure } \\
\text { and PAH diagnosis } \\
\text { months }\end{array}$ & $108(60-144)$ & $78(43-140)$ & NS \\
\hline $\begin{array}{l}\text { Anorexigen exposure } \\
\text { duration months }\end{array}$ & $30(12-70)$ & $6(3-12)$ & $<0.001$ \\
\hline \multicolumn{4}{|l|}{ NYHA-FC } \\
\hline$\|$ & $12(17)$ & $15(14)$ & \\
\hline III & $52(74)$ & $71(65)$ & NS \\
\hline IV & $6(9)$ & $23(21)$ & \\
\hline 6MWD m & 319 (209-372) & $250(121-355)$ & $<0.01$ \\
\hline \multicolumn{4}{|l|}{ Haemodynamics } \\
\hline Pra $\mathrm{mmHg}$ & $9 \pm 5$ & $11 \pm 6$ & $<0.05$ \\
\hline Mean PAP mmHg & $47 \pm 11$ & $60 \pm 12$ & $<0.0001$ \\
\hline Ppow mmHg & $10 \pm 4$ & $9 \pm 3$ & NS \\
\hline $\mathrm{CI} \mathrm{L} \cdot \mathrm{min}^{-1} \cdot \mathrm{m}^{-2}$ & $2.4 \pm 0.6$ & $2.2 \pm 0.6$ & NS \\
\hline PVRI $\mathrm{mmHg} \cdot \mathrm{L}^{-1} \cdot \mathrm{min}^{-1} \cdot \mathrm{m}^{-2}$ & $17 \pm 8$ & $26 \pm 11$ & $<0.0001$ \\
\hline
\end{tabular}

Data are presented as median (interquartile range), $\mathrm{n}(\%)$ or mean $\pm \mathrm{SD}$, unless otherwise stated. M: male; F: female; BMI: body mass index; NYHA-FC: New York Heart Association-functional class; 6MWD: 6-min walk distance; Pra: right atrial pressure; PAP: pulmonary artery pressure; Ppcw: pulmonary capillary wedge pressure; $\mathrm{Cl}$ : cardiac index; PVRI: pulmonary vascular resistance index; NS: not significant ${ }^{\#}$ : comparison between continuous data was performed using an unpaired t-test. A Chi-squared test was used for group data comparison.

of sickle cell disease; one case of familial PAH; and one case of abnormal pulmonary venous return.

The current cohort of patients with pre-capillary $\mathrm{PH}$ and benfluorex exposure was compared with those patients from the French registry with $\mathrm{PAH}$ and prior exposure to fenfluramine derivatives (table 1) [12]. Those with benfluorex were $\sim 10 \mathrm{yrs}$ older at time of diagnosis. The proportion of males with a history of benfluorex exposure (male to female ratio 1:3) was greater than that exposed to fenfluramine derivatives (male to female ratio 1:19). The median duration of exposure to benfluorex was markedly longer compared with that of the fenfluramine derivatives. The median interval between initial drug exposure and $\mathrm{PAH}$ diagnosis was not significantly longer among patients taking benfluorex compared with those that had been exposed to fenfluramine derivatives. Compared with patients that had taken fenfluramine derivatives, patients with benfluorex exposure exhibited slightly less severe haemodynamic abnormality (pulmonary vascular resistance values were $\sim 25 \%$ lower).
The presence of a BMPR2 mutation was evaluated in 13 sporadic cases of pre-capillary PAH exposed to benfluorex. In total, two $(15 \%)$ patients carried a BMPR2 mutation. Furthermore, we identified a patient with familial $\mathrm{PAH}$ and exposure to benfluorex (unfortunately, BMPR2 mutation has not yet been sequenced in this patient).

\section{Characteristics of patients with mixed pre- and post- capillary $\mathbf{P H}$}

Evidence of mixed pre- and post-capillary $\mathrm{PH}$ was observed in $13(16 \%)$ out of 85 patients. Nine of these individuals had systemic hypertension, itself a risk factor for diastolic left ventricle dysfunction. Individual data for these patients are shown in table 2.

\section{Mitral and/or aortic valvular heart disease}

Mitral and/or aortic valvular heart disease was identified by echocardiography among $23(28 \%)$ out of 83 patients with either pre-capillary or mixed pre- and post-capillary $\mathrm{PH}$. The proportion of patients with evidence of associated cardiac valvulopathy was greater among patients with mixed pre- and post-capillary $\mathrm{PH}$ when compared with patients with "pure" pre-capillary $\mathrm{PH}$ (seven (54\%) out of 13 versus 16 (23\%) out of 70 , respectively; $p=0.02)$. There was evidence of significant mitral valve disease in 10 patients and significant aortic valve disease in seven. Mixed aortic and mitral valve disease was identified in six individuals. Morphological abnormalities compatible with benfluorex toxicity have been described in seven patients $(8.2 \%)$. Details regarding valvular heart disease involvement are summarised in table 3.

\section{Outcomes}

Median time of follow-up was 10 months. The majority of patients diagnosed with pre-capillary $\mathrm{PH}$ are currently treated by one or more specific PAH therapeutic agents (endothelin receptor antagonists, phosphodiesterase type 5 inhibitors or prostacyclin analogues). At median time of last follow-up, eight patients had died. Two patients had undergone lung transplantation, of which one patient died in the immediate post-operative period.

\section{DISCUSSION}

From June 1999 to March 2011, we identified 85 cases of PH associated with benfluorex exposure in the French PAH Network. Of these, 70 patients had confirmed pre-capillary PH. Approximately one-quarter of all patients also had exposure to fenfluramine or dexfenfluramine, and an additional risk factor for $\mathrm{PH}$ was identified in one-third of patients. From 2006 onward, we observed an annual increase in the number of cases of $\mathrm{PH}$ associated with benfluorex exposure. The majority of study subjects were overweight or obese and the presence of at least one other major risk factor for cardiovascular disease was identified in $80 \%$ of the patients. However, this finding is not surprising as patients with these comorbidities correspond to the population for whom benfluorex was in general prescribed. Interestingly, we observed a relatively high proportion of patients $(26 \%)$ that had both $\mathrm{PH}$ and aortic and/or mitral valve disease, such findings may also be accounted for by norfenfluramine toxicity. This is in marked contrast with the findings of previous French and US studies of patients with fenfluramine exposure or its derivatives that 


\begin{tabular}{|c|c|c|c|c|c|c|c|}
\hline Patient & $\begin{array}{c}\text { Systemic } \\
\text { hypertension }\end{array}$ & $\begin{array}{l}\text { Associated valvular } \\
\text { insufficiency }\end{array}$ & Pra $\mathrm{mmHg}$ & $\begin{array}{l}\text { Systolic/diastolic/ } \\
\text { mean PAP mmHg }\end{array}$ & $\begin{array}{l}\text { Ppcw } \\
\mathrm{mmHg}\end{array}$ & $\begin{array}{l}\mathrm{TPG} \\
\mathrm{mmHg}\end{array}$ & $\begin{array}{c}\text { PVRI } \\
\mathrm{mmHg} \cdot \mathrm{L}^{-1} \cdot \mathrm{min}^{-1} \cdot \mathrm{m}^{-2}\end{array}$ \\
\hline 1 & Yes & Mild mitral insufficiency & 14 & $105 / 40 / 65$ & 29 & 36 & 11.2 \\
\hline 2 & Yes & Mild aortic insufficiency & 15 & $60 / 28 / 40$ & 18 & 22 & 6.7 \\
\hline 4 & Yes & Mild mitral insufficiency & 18 & $101 / 29 / 55$ & 26 & 29 & 9.7 \\
\hline 5 & Yes & No & 11 & $58 / 22 / 38$ & 16 & 22 & 11 \\
\hline 6 & No & $\begin{array}{l}\text { Mild aortic and moderate } \\
\text { mitral insufficiency }\end{array}$ & 9 & $65 / 34 / 47$ & 31 & 16 & 6.6 \\
\hline 7 & Yes & No & 17 & $73 / 37 / 52$ & 24 & 28 & 8.2 \\
\hline 8 & No & No & 18 & $70 / 22 / 41$ & 19 & 22 & 7.6 \\
\hline 13 & Yes & Mild mitral insufficiency & 11 & $75 / 25 / 49$ & 22 & 27 & 9.6 \\
\hline
\end{tabular}

Pra: right atrial pressure; PAP: pulmonary arterial pressure; Ppcw: pulmonary capillary wedge pressure; TPG: transpulmonary gradient; PVRI: pulmonary vascular resistance index.

showed increased incidences of either isolated PAH [12] or isolated valvular heart disease, respectively [25].

Baseline clinical and functional characteristics of benfluorexassociated PH patients were broadly similar to the cohort of PAH patients exposed to fenfluramine and its derivatives [20]. However, with regard to length of drug exposure, some differences were also apparent between these populations. In particular, the median duration of exposure to benfluorex was significantly longer than that reported with fenfluramine and its derivatives. This difference is most likely due to the fact that benfluorex was generally prescribed as a long-term treatment for overweight patients that had diabetes and/or metabolic syndrome. In contrast, fenfluramine and its derivatives were exclusively used as anorexigens and in general treatment was prescribed on a short-term basis (generally $<6$ months) [20]. Benfluorex, as are fenfluramine and dexfenfluramine, is metabolised into norfenfluramine a 5-HT2B agonist [26]. Whereas dexfenfluramine is given once a day $(60 \mathrm{mg})$, recommended treatment using benfluorex is three times per day $(450 \mathrm{mg})$. These dexfenfluramine and benfluorex usual dosages led to the same plasmatic concentration of norfenfluramine $\left(50 \mathrm{ng} \cdot \mathrm{mL}^{-1}\right)$ [27]. However, most patients exposed to benfluorex had a prescribed dosage at $300 \mathrm{mg}$ or even $150 \mathrm{mg}$ per day, leading to a norfenfluramine plasmatic concentration lower than that found in fenfluramine users [28]. Interestingly, despite the longer median duration of benfluorex treatment, no significant difference in the interval between the initial drug exposure and date of $\mathrm{PH}$ diagnosis was observed between the two populations. The observation that patients exposed to benfluorex were older and showed a less marked female preponderance compared to fenfluramine and its derivatives is likely to be accounted for by the different therapeutic indications of the respective agents corresponding with the two different populations [20].

Compared with the cohort with fenfluramine exposure, patients exposed to benfluorex that had $\mathrm{PH}$ showed reduced marked haemodynamic impairment as evidenced by lower levels for mean PAP and pulmonary vascular resistance. We also observed the same proportion of patients that had a positive response after acute vasodilator testing $(5.7 \%)$ as has been described in other studies of patients with idiopathic PAH [19]. The same proportion of such "responders" was also reported in populations exposed to fenfluramine and its derivatives [20].

A relatively high proportion of patients in our study had at least one other potential risk factor for the development of $\mathrm{PH}(30 \%)$. As previously discussed, these patients were typically obese. Although obesity is not a known independent risk factor for PAH [13], it is nonetheless associated with other conditions that themselves predispose to other forms of $\mathrm{PH}$, such as obstructive sleep apnoea, chronic thromboembolic disease and left heart disease. In addition, some patients had other associated conditions that may promote the development of PAH (like portal hypertension or systemic sclerosis). Similarly, The Surveillance of North American Pulmonary Hypertension reported a high rate of anorexigen use in "secondary" PH too (11.4\%) [29]. These observations suggest that multiple risk factors for PH may have additive effects.

A quarter of the overall cohort patients with benfluorex exposure and $\mathrm{PH}$ had as a risk factor additional prior exposure to fenfluramine or one of its derivatives for a median duration of 11 months. In all cases, exposure to the fenfluramine derivatives was prior to benfluorex exposure. The median time between start of fenfluramine use and $\mathrm{PH}$ diagnosis was 
TABLE 3 Associated valvular heart diseases in patients assessed for pulmonary hypertension (PH) associated with benfluorex

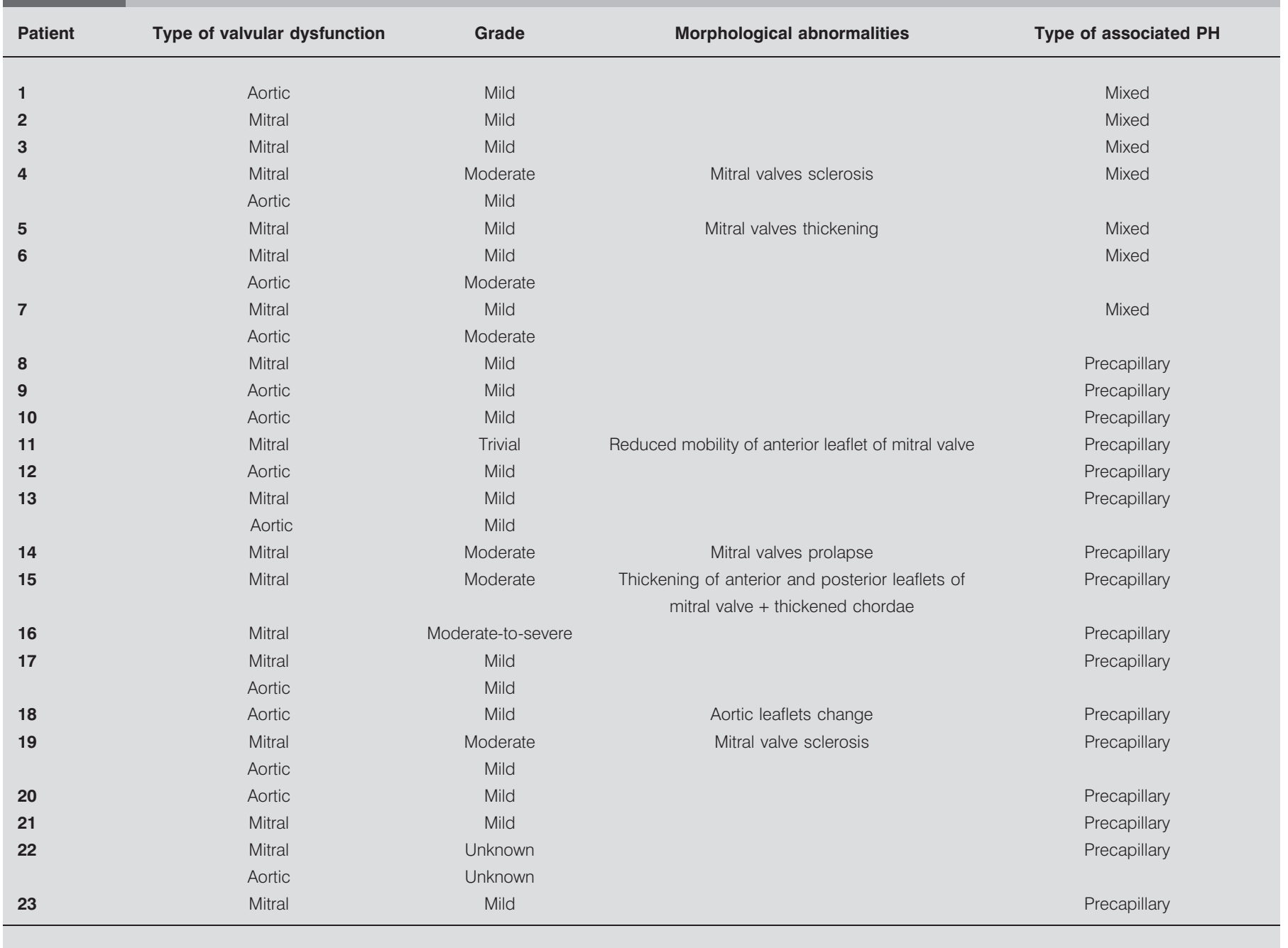

21 yrs (interquartile range 6-36 yrs), which is higher than previously described in the French patients who developed fenfluramine-associated PAH [9, 20]. Furthermore, haemodynamic characteristics of patients exposed to both benfluorex and fenfluramine or its derivates were not different from those of patients exposed to benfluorex only (data not shown). None of these data can suggest that combined exposure was more harmful than benfluorex exposure alone. These observations corroborate the hypothesis that the additional exposition to benfluorex was likely to trigger the occurrence of the pulmonary vascular disease in these patients. However, one cannot exclude a priming effect of initial fenfluramine exposure.

Interestingly, the presence of BMPR2 mutations has been examined in 13 patients and resulted in mutated genes being found in two patients with. This proportion is similar to what has been found in a population of patients with idiopathic $\mathrm{PAH}$ or fenfluramine associated PAH [20, 30, 31]. This finding corroborates the concept that benfuorex-induced PAH shares genetic predisposition features with idiopathic PAH.

These observations underscore the complex nature of $\mathrm{PAH}$ pathogenesis. Anorexigens may precipitate pulmonary vascular disease in patients with predisposing factors or underlying conditions associated with a higher risk for developing $\mathrm{PH}$. Anorexigen use could play a triggering role for both populations.

Furthermore, haemodynamic evaluation identified some patients with mixed pre- and post-capillary $\mathrm{PH}$. The majority of these patients had systemic hypertension; a known risk factor for the development of diastolic left-ventricle dysfunction, which itself can contribute to increases in PAP. Approximately half of these patients had associated valvular heart disease, a factor that is likely to have contributed to the post-capillary component of PH observed in this subgroup. In these patients, we cannot exclude benfluorex from playing a role in the precapillary component of $\mathrm{PH}$.

Prior exposure to appetite suppressants is now firmly established as aetiologically relevant for the development of both cardiac valvular disease and PAH. Hitherto, published series have not described the coexistence of both these cardiovascular complications following exposure to anorexigens. In France, fenfluramine and its derivatives were removed from the market following an epidemic of PAH in the late 1980s and early 1990s. However, cardiac valvular disease was rarely reported 
following exposure to this class of drug in France [12]. In contrast, severe cardiac valvulopathy was the first cardiovascular side-effect described in patients in the USA that had been prescribed a combination of fenfluramine/phentermine ("fenphen"), the latter agent being an amphetamine derivative [25].

Interestingly, one-quarter of patients in the current series showed coexisting $\mathrm{PH}$ and mild-to-moderate cardiac valve disease. This finding could be explained at least in part by the longer duration of exposure to benfluorex. The concomitant development of both these cardiovascular side-effects, as was found in our population, strengthens the hypothesis that these toxicities were directly attributable to fenfluramine-like cardiovascular effects of benfluorex exposure. No particular factor could be attributed to the relatively high proportion of patients that had both $\mathrm{PH}$ and valvular cardiac disease. Interestingly, the proportion of patients with cardiac valvular structural abnormalities identified in our series is strikingly similar to the incidence of valvular dysfunction that was observed in the "REGULATE" (Randomised, double-blind study with comparison of bEnfluorex versus pioGlitazone in combination with sULfonylurea administered orAlly for the Treatment of type 2 diabEtes) study undertaken by Servier Pharma (Suresnes, France) of patients exposed to benfluorex who were evaluated at baseline and after 12 months by echocardiography [32]. The objective of the REGULATE study was to compare, during 52week period, the efficacy and safety of two "antidiabetic" oral treatments (benfluorex versus pioglitazone). It included 847 patients with type 2 diabetes. Results, based on the comparison of echocardiography at baseline and after $1 \mathrm{yr}$ of treatment, showed statistically significant emergent valvular regurgitation in patients treated with benfluorex in comparison with patients treated with pioglitazone $(26.5 \%$ versus $10.9 \%$; $\mathrm{p}<0.0001)$. Morphological abnormalities of the valves were also observed twice as often with benfluorex ( $2.6 \%$ versus $1.3 \%$; $\mathrm{p}<0.264)$. The findings of this industry-sponsored study, in conjunction with results from a separate case-control study by FRACHON et al. [15] that also highlighted the potential cardiac toxicity of benfluorex, led directly to its withdrawal in 2009 from the French market.

The first case investigated at the French $\mathrm{PH}$ referral centre of a patient with prior exposure to benfluorex who developed $\mathrm{PAH}$, was documented in 1999 [17]. Thereafter, a relatively small number of cases were identified during the period 1999-2005. In contrast, a dramatic increase in the number of the cases was observed from 2006 onwards. The reasons for the observed latter increase in incidence are unclear but may be related to the fact that between its initial approval in 1976 and the mid-1990s the number of patients prescribed benfluorex remained relatively low. However, following the withdrawal from the market of several popular anorexigens, sales of benfluorex rose substantially. Indeed, approximately two-thirds of the total sales of benfluorex in France were recorded during the period 2000-2009, which is a temporal argued for benfluorex imputability [33]. The French national fund of health insurance reported that between 200,000-300,000 patients per year were exposed to benfluorex during the period 2006-2009 and that seven million boxes of benfluorex were sold each year during this period. In addition, a greater awareness among clinicians of the potential toxic effects of benfluorex following the publication of the initial series by BOUTET et al. [17] and publications of reports in the press may also have contributed to the increased incidence observed towards the end of our study.

To include an optimum number of benfluorex-exposed patients, we did solicit all centres of the French PAH Network, in order to identify from their records all $\mathrm{PH}$ cases associated with benfluorex exposure before $\mathrm{PH}$ diagnosis. The retrospective analysis of data is a limitation of this report as it does not guarantee an optimal identification of all patients especially before the creation of the French PAH Network. Another limitation of this study is that benfluorex exposure history was collected by the patients themselves. We were not able to validate systematically drug exposure through medical charts or pharmacy records.

In conclusion, the revelations about the cardiovascular sideeffects of benfluorex led to an embarrassing political and medical scandal in France and highlighted significant deficiencies in the French pharmacovigilance system [16, 34]. The results of our present study, together with the accumulated data regarding the known toxic effects of fenfluramine and dexfenfluramine, strongly suggest an aetiological link between benfluorex exposure and the development of PAH. Although an additional larger case-control study is required to further strengthen hypothesis of a pathogenic role for benfluorex in the development of PAH, it is unlikely such a study will ever be undertaken given that this agent has now been withdrawn from the market. As PAH is an unequivocal severe consequence of cardiovascular toxicity of several drugs and toxins, one should investigate in great detail all cases referred for so-called unexplained PAH in order to identify whether a toxic exposure may have acted as a trigger for $\mathrm{PAH}$ [35].

\section{STATEMENT OF INTEREST}

Statements of interest for L. Savale, V. Cottin, E. Bergot, I. Frachon, G. Prevot, C. Pison, N. Lamblin, M. Reynaud-Gaubert, A. Bourdin, O. Sanchez, X,. Jaïs, D. Montani, O. Sitbon, G. Simonneau and M. Humbert can be found at www.erj.ersjournals.com/site/misc/statements.xhtml

\section{ACKNOWLEDGEMENTS}

L. Savale, X. Jaïs, D. Montani, O. Sitbon, G. Simonneau and M. Humbert: Univ Paris-Sud, Faculté de Médecine and AP-HP Centre de Référence de l'Hypertension Pulmonaire Sévère, Service de Pneumologie et Soins Intensifs, Hôpital Bicêtre, Le Kremlin Bicêtre, and INSERM U999 Hypertension Artérielle Pulmonaire: Physiopathologie et Innovation Thérapeutique, Centre Chirurgical Marie-Lannelongue, Le PlessisRobinson, France. M-C Chaumais: Univ Paris-Sud, Faculté de Médecine, Le Kremlin-Bicêtre, INSERM U999 Hypertension Artérielle Pulmonaire: Physiopathologie et Innovation Thérapeutique, Centre Chirurgical Marie-Lannelongue, Le Plessis-Robinson, and AP-HP, Service de Pharmacie, Hôpital Antoine Béclère, Clamart, France. V. Cottin: HCL, Centre de référence des maladies pulmonaires rares, Service de Pneumologie, Hôpital Louis-Pradel; Université Claude Bernard Lyon 1, Lyon, France. E. Bergot: Service de Pneumologie, Centre Hospitalier Universitaire, Caen, France. I. Frachon: CHU de la Cavale Blanche, Groupe HTAP de Bretagne Occidentale Dept de médecine interne et de pneumologie, EA 3878 (GETBO), IFR 148, Brest, France. G. Prevot: Service de Pneumologie, Hôpital Larrey, CHU, Toulouse; France. C Pison: Dept Cancérologie, Médecine Aiguë Spécialisée CHU and Université Joseph Fourier; Inserm 1055, Grenoble, France. C. Dromer: Service de Chirurgie Thoracique, Hôpital du Haut Levesque, CHU, Bordeaux, France. P. Poubeau: Service des Maladies Infectieuses, GHSR, St-Pierre, La Réunion, France. N. Lamblin: Service de Cardiologie, Hôpital Cardiologique, 
CHRU, Lille, France. G. Habib: Service de Cardiologie, Hôpital de la Timone, CHU, Marseille, France. M. Reynaud-Gaubert: Service de Pneumologie, CHU Nord, AP-HM, Université de la méditerranée, AixMarseille II, Marseille, France. A. Bourdin: Service des maladies respiratoires, Hôpital Arnaud-de-Villeneuve, CHU, Montpellier, France. O. Sanchez: Université Paris Descartes, Sorbonne Paris Cité and APHP, Service de Pneumologie et Soins Intensifs, Hôpital Européen Georges-Pompidou, Université Paris-V, Paris, France. P. Tubert-Bitter: INSERM, CESP Centre de recherches en épidémiologie et santé des populations, U1018, Equipe biostatistique, F-94807, and Université Paris-Sud, UMRS 1018, F-94807, Villejuif, France.

The authors would like to thank the following members of the French PAH Network who have contributed to the conduct of this study: A. Yaïci, D. Natali, F. Parent, L. Rottat (AP-HP, Hôpital Bicêtre, Le Kremlin Bicêtre), L. Têtu (Hôpital Larrey, Toulouse), S. Renard (AP-HM, Hôpital La Timone, Marseille), J-F. Cordier (Hospices Civils de Lyon, Hôpital Louis-Pradel , Lyon), P. De Groote (Hôpital Cardiologique, Lille), R. Magnier (Centre Hospitalier Universitaire, Caen), A. Chaouat (Centre Hospitalier Universitaire, Nancy), M. Canuet (Centre Hospitalier Universitaire, Strasbourg), J. Inamo (Centre Hospitalier Universitaire, Martinique), C. Chabanne (Centre Hospitalier Universitaire, Rennes), and F. Soubrier (AP-HP, Hôpital Pitié-Salpêtrière, Université Pierre et Marie Curie, Paris, all France). We also thank D.S. O'Callaghan (Centre for Lung Health, Mater Misericordiae University Hospital, Dublin, Ireland) who contributed to the writing of this article.

\section{REFERENCES}

1 Farber HW, Loscalzo J. Pulmonary arterial hypertension. N Engl J Med 2004; 351: 1655-1665.

2 Humbert M, Sitbon O, Simonneau G. Treatment of pulmonary arterial hypertension. N Engl J Med 2004; 351: 1425-1436.

3 Galiè N, Hoeper MM, Humbert M, et al. Guidelines for the diagnosis and treatment of pulmonary hypertension: the Task Force for the Diagnosis and Treatment of Pulmonary Hypertension of the European Society of Cardiology (ESC) and the European Respiratory Society (ERS), endorsed by the International Society of Heart and Lung Transplantation (ISHLT). Eur Heart J 2009; 30: 2493-2537.

4 Gurtner HP. Chronische pulmonale Hypertonie vaskularen Ursprungs, plexogene pulmonale Arteriopathie und der Appetitzugler Aminorex: Nachlese zu einer Epidemie [Chronic pulmonary hypertension of vascular etiology, plexogenic pulmonary arteriopathy and the appetite depressant Aminorex lessons from an epidemic]. Schweiz Med Wochenschr 1985; 115: 818-827.

5 Gurtner HP. Chronische pulmonale Hypertonie vaskularen Ursprungs, plexogene pulmonale. Arteriopathie und der Appetitzugler Aminorex: Nachlese zu einer Epidemie [Chronic pulmonary hypertension of vascular origin, plexogenic pulmonary arteriopathy and the appetite depressant aminorex: addenda to an epidemic]. Schweiz Med Wochenschr 1985; 115: 782-789.

6 Hatano S, Strasser T. Primary Pulmonary Hypertension: Report on a WHO Meeting, Geneva, 15-17 October 1973. Geneva, World Health Organization, 1975.

7 Morrell NW, Adnot S, Archer SL, et al. Cellular and molecular basis of pulmonary arterial hypertension. J Am Coll Cardiol 2009; 54: S20-S31.

8 Eddahibi S, Adnot S. Anorexigen-induced pulmonary hypertension and the serotonin (5-HT) hypothesis: lessons for the future in pathogenesis. Respir Res 2002; 3: 9.

9 Humbert M, Sitbon O, Chaouat A, et al. Pulmonary arterial hypertension in France: results from a national registry. Am J Respir Crit Care Med 2006; 173: 1023-1030.

10 Douglas JG, Munro JF, Kitchin AH, et al. Pulmonary hypertension and fenfluramine. Br Med J (Clin Res Ed) 1981; 283: 881-883.
11 Roche N, Labrune S, Braun JM, et al. Pulmonary hypertension and dexfenfluramine. Lancet 1992; 339: 436-437.

12 Brenot F, Herve P, Petitpretz P, et al. Primary pulmonary hypertension and fenfluramine use. Br Heart J 1993; 70: 537-541.

13 Abenhaim L, Moride Y, Brenot F, et al. Appetite-suppressant drugs and the risk of primary pulmonary hypertension. International Primary Pulmonary Hypertension Study Group. $N$ Engl J Med 1996; 335: 609-616.

14 Walker AM, Langleben D, Korelitz JJ, et al. Temporal trends and drug exposures in pulmonary hypertension: an American experience. Am Heart J 2006; 152: 521-526.

15 Frachon I, Etienne Y, Jobic Y, et al. Benfluorex and unexplained valvular heart disease: a case-control study. PLoS One 2010; 5: e10128.

16 Mullard A. Mediator scandal rocks French medical community. Lancet 2011; 377: 890-892.

17 Boutet K, Frachon I, Jobic Y, et al. Fenfluramine-like cardiovascular side-effects of benfluorex. Eur Respir J 2009; 33: 684-688.

18 Galiè N, Hoeper MM, Humbert M, et al. Guidelines for the diagnosis and treatment of pulmonary hypertension. Eur Respir J 2009; 34: 1219-1263.

19 Sitbon $\mathrm{O}$, Humbert $\mathrm{M}$, Jaïs $\mathrm{X}$, et al. Long-term response to calcium channel blockers in idiopathic pulmonary arterial hypertension. Circulation 2005; 111: 3105-3111.

20 Souza R, Humbert M, Sztrymf B, et al. Pulmonary arterial hypertension associated with fenfluramine exposure: report of 109 cases. Eur Respir J 2008; 31: 343-348.

21 Deng Z, Morse JH, Slager SL, et al. Familial primary pulmonary hypertension (gene PPH1) is caused by mutations in the bone morphogenetic protein receptor-II gene. Am J Hum Genet 2000; 67: 737-744.

22 Lancellotti P, Moura L, Pierard LA, et al. European Association of Echocardiography recommendations for the assessment of valvular regurgitation. Part 2: mitral and tricuspid regurgitation (native valve disease). Eur J Echocardiogr 2010; 11: 307-332.

23 Vahanian A, Baumgartner $\mathrm{H}$, Bax J, et al. Guidelines on the management of valvular heart disease: The Task Force on the Management of Valvular Heart Disease of the European Society of Cardiology. Eur Heart J 2007; 28: 230-268.

24 Bondon-Guitton E, Prevot G, Didier A, et al. Pulmonary arterial hypertension and benfluorex: 5 case reports. Therapie 2011; 66: 135-138.

25 Connolly HM, Crary JL, McGoon MD, et al. Valvular heart disease associated with fenfluramine-phentermine. N Engl J Med 1997; 337: 581-588.

26 Noize $\mathrm{P}$, Sauer M, Bruneval $\mathrm{P}$, et al. Valvular heart disease in a patient taking benfluorex. Fundam Clin Pharmacol 2006; 20: 577-578.

27 Inspection Générale des Affaires Sociales. www.igas.gouv.fr/spip. php?article161 Date last updated: January, 2011. Date last accessed: August, 2012.

28 ANSM. Cnamts. Note complémentaire destinée à l'Afssaps: benfluorex et décès. http://ansm.sante.fr/var/ansm_site/storage/ original/application/d579a3f3ec347b90d16e5ab6c7119e65.pdf Date last updated: September 2010. Date last accessed: August, 2012.

29 Rich S, Rubin L, Walker AM, et al. Anorexigens and pulmonary hypertension in the United States: results from the surveillance of North American pulmonary hypertension. Chest 2000; 117: 870-874.

30 Sztrymf B, Coulet F, Girerd B, et al. Clinical outcomes of pulmonary arterial hypertension in carriers of BMPR2 mutation. Am J Respir Crit Care Med 2008; 177: 1377-1383.

31 Humbert M, Deng Z, Simonneau G, et al. BMPR2 germline mutations in pulmonary hypertension associated with fenfluramine derivatives. Eur Respir J 2002; 20: 518-523. 
32 Derumeaux G, Ernande L, Serusclat A, et al. Echocardiographic evidence for valvular toxicity of benfluorex: a double-blind randomised trial in patients with type 2 diabetes mellitus. PLoS One 2012; 7: e38273.

33 Hill C. Mortalite attribuable au benfluorex (Mediator $\mathbb{E}$ ) [Number of deaths attributable to benfluorex]. Presse Med 2011; 40: 462-469.
34 Frachon I. Benfluorex (Mediator $\mathbb{\circledR}$ ), notre vigilance en question [Benfluorex (Mediator ${ }^{\circledR}$ ), our vigilance in question]. Presse Med 2011; 40: 459-461.

35 Humbert M, Simonneau G, Dinh-Xuan AT. Whistleblowers. Eur Respir J 2011; 38: 510-511. 